\title{
Effects of Leucaena leucocephala (Lam.) de Wit Leaves Extracts in Culture of Human Umbilical Vein Cells
}

\author{
Ratikorn Chatchanayuenyong ${ }^{1,2 *}$, Patcharawan Sujayanont ${ }^{1,2}$, Auranut Vuttivirojana ${ }^{1}$
}

\section{Ratikorn Chatchanayue- nyong ${ }^{1,2 *}$, Patcharawan Sujayanont ${ }^{1,2}$, Auranut Vuttivirojana ${ }^{1}$}

\section{'Biomedical Department, Faculty of Medicine, Mahasarakham University, Mahasarakham, THAILAND. \\ ${ }^{2}$ Clinical Epidemiology Unit, Faculty of Medicine, Mahasarakham University, Mahasarakham, THAILAND. \\ Correspondence}

Ratikorn Chatchanayuenyong

Biomedical Department, Faculty of Medicine, Mahasarakham University, Mahasarakham, THAILAND.

Phone No: +66(0) 43712992

E-mail: ratikorn.c@msu.ac.th

History

- Submission Date: 10-10-2017;

- Review completed: 08-11-2017;

- Accepted Date: 20-11-2017

\section{DOI : 10.5530/pj.2018.1.25}

Article Available online

http://www.phcogj.com/v10/i1

\section{Copyright}

(c) 2018 Phoog.Net. This is an openaccess article distributed under the terms of the Creative Commons Attribution 4.0 International license.

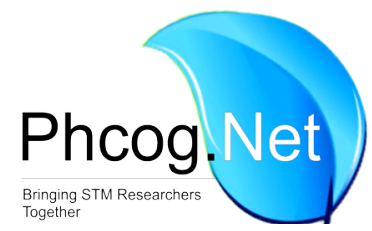

\begin{abstract}
Oxidative stress can induce vascular endothelial dysfunction in diabetic and hyperlipidemia patients. Leucaena leucocephala (Lam.) de Wit has been reported of possessing antioxidant, antidiabetic and anticholiesterase activity; as well as the toxic substance called mimosine. Aims: To determine antioxidant effects of Leucaena leucocephala (Lam.) de Wit Leave extracts in oxidative stress induced vascular endothelial function. Methods and Material: Leave extracts were determined for antioxidant activity. Either or both of oxidized low density lipoprotein (oxLDL) and glucose were applied to induce oxidative stress condition in human umbilical vein cultured (HUVCs) to observe superoxide dismutase (SOD) activity, nitric oxide (NO) level and morphological changes. Results: Total polyphenol and flavonoid were 51.04 $\pm 0.91 \mathrm{mg} \mathrm{GAE} / \mathrm{g}$ and $0.13 \pm 0.01 \mathrm{mg}$ catechin/g of dried weight (DW), respectively. Free radical reduction efficiency of crude extract observed by 1,1-diphenyl-2-picrylhydrazyl (DPPH) assay showed $\mathrm{IC}_{50}$ value of $329.6 \mu \mathrm{g}$ of vitamin $\mathrm{C}$ equivalent/mg of extracts. Frap value was showed $428.54 \pm 15.32 \mathrm{mM}$ Fell equivalent/g of DW. The result observing in HUVCs showed that comparing to the control, SOD activity, NO and MDA level were maintained in $0.05 \mathrm{mg} / \mathrm{mL}$ of $L$. leucocephala treated group, but $N O$ and MDA level were lowered when comparing with oxLDL and glucose-induced oxidative stress. No change was observed in $0.05 \mathrm{mg} / \mathrm{mL}$ of L. leucocephala treated group, comparing with control group. Conclusion: This study has been performed to exhibit the antioxidant activity of $L$. leucocephala in endothelium functions and has been found to have an appropriate concentration at $0.05 \mathrm{mg} / \mathrm{mL}$ in reducing oxidative stress condition in impaired fasting blood glucose patients. Nevertheless, the optimal level for toxic activity in inhibition of cancer angiogenesis should be further investigated.

Key words: Leucaena leucocephala (Lam.), De Wit, Antioxidant activity, Nitric oxide, Superoxide dismutase, Vascular endothelial.
\end{abstract}

\section{INTRODUCTION}

Impaired fasting glucose (IFG) is a type of prediabetes that found in those with increasing of fasting blood glucose but not yet develop diabetes mellitus. ${ }^{1}$ Several studies have suggested that rising of blood glucose can be induced by the elevation of oxidative stress, through the production of reactive oxygen species (ROS) that influence insulin resistance and eventually result in beta-cell dysfunction and diabetes mellitus. ${ }^{2,3}$ The ROS are also initiate a chain reaction, and result in reduction of nitric oxide (NO) availability and presentation of several inflammation markers. Altogether, these events lead to dysfunction of endothelial cell and development of cardiovascular disease. ${ }^{4}$

Cardiovascular diseases (CVS) contribute to most noncommunicable diseases (NCDs) with 17.5 million in year 2012, and was predicted to increase to 592 million in year 2035..$^{5}$ It is known that an impairment of NO production ${ }^{6,7}$ and scavenger enzyme such as superoxide dismutase (SOD) can be resulting in oxidative stress. ${ }^{8}$ This event is eventually leading to endothelial dysfunction, and tissue injury of vascular cells.
Endothelial dysfunction can be found in patients with diabetes, ${ }^{2,9,10}$ hyperlipidemia, and atherosclerosis and hypertension. ${ }^{10,11}$ Other than NO and SOD, the reported potential biomarkers of endothelial dysfunctions is oxidized low-density lipoprotein (oxLDL), as well as malondialdehyde (MDA) that have been expressed in vascular diseases. ${ }^{12,13,14}$ Several Thai traditional herbal medicines have been suggested as providing antioxidant activities, and one of them are Leucaena leucocephala (Lam) de Wit.

L. leucocephala has been reported of processing antioxidant activities by providing important substances such as flavonoids, terpenes and coumarins, sterols. ${ }^{15}$ It has been reported for lowering blood glucose, blood pressure and NO level, and providing hypochlolesteromic, anti-inflammatory and antioxidant activity. ${ }^{16,17,18}$ In previous studies, glucose and LDL can induce endothelial dysfunction of the vessels in diabetic and cardiovascular patients. ${ }^{9,19,20}$ Thus, optimal level of L. leucocephala may protect vascular cell through reduction of LDL and glucose

Cite this article: Chatchanayuenyong $R$, Sujayanont $P$, Vuttivirojana A. Effects of Leucaena leucocephala (Lam.) de Wit Leaves Extracts in Culture of Human Umbilical Vein Cells. Pharmacog J. 2018;10(1):148-53. 
oxidation. Altogether, it leads to objective of the study, to observe antioxidant activity of L. leucocephala in endothelium function using impair fasting glucose in human umbilical vein cultured (HUVCs) model.

\section{MATERIAL AND METHOD}

\section{Extracts preparation}

Fresh leaves of $L$. leucocephala were collected from Sakolnakorn province, Thailand. Leaves were dried at $60^{\circ} \mathrm{C}$ and then immersed in $90 \%$ ethanol for 3 days. The solution was evaporated using rotary evaporator (BossTech, Scientific Instruments) followed by lyophilization. Prior to the experiment, leave extract preparing in $50 \%$ ethanol was filtrated by membrane filter $(0.45 \mu \mathrm{m}$-pore size $)$ and diluted to different concentrations $(0.05,0.1,0.5$ and $1 \mathrm{mg} / \mathrm{ml}$ ).

\section{Determination of antioxidant contents}

The antioxidant properties of total phenolic content (TPC) are potential for inhibiting lipid peroxidation. TPC concentration was estimated with Folin-Ciocalteu reagent using gallic acid as standard, described previously. ${ }^{21}$ Briefly, $10 \%$ Folin-Ciocalteu reagent and $10.75 \% \mathrm{Na}_{2} \mathrm{CO}_{3}$ were mixed with L. leucocephala. TPC product was measured at $760 \mathrm{~nm}$ spectrophotometrically and was calculated from standard curve of gallic acid and expressed as mg GAE/g of sample dried weight.

Total flavonoid content (TFC) was determined by the aluminum chloride colorimetric method according to Zhishen J et al..$^{22} \mathrm{~L}$. leucocephala was incubated in $5 \% \mathrm{NaNO}_{2}$ at room temperature for $5 \mathrm{~min}$, and followed by $10 \% \mathrm{AlCl}_{3}$ for $5 \mathrm{~min}$ and $1 \mathrm{M} \mathrm{NaOH}$. The mixture was incubated at room temperature for $15 \mathrm{~min}$ and measured absorbance at $510 \mathrm{~nm}$ with UVspectrophotometer. TFC was calculated from standard curve as catechin and expressed as mg of catechin/g of sample dry weight.

\section{Antioxidant activity \\ 1,1-diphenyl-2-picrylhydrazyl (DPPH) radical scavenging activity}

DPPH assay was performed to measure scavenging activity. ${ }^{23}$ Briefly, leave extracts were dissolved in $0.5 \mathrm{nM} \mathrm{DPPH}$ to final concentration as following, $6.125 \mu \mathrm{g} / \mathrm{ml}, 12.5 \mu \mathrm{g} / \mathrm{ml}, 25 \mu \mathrm{g} / \mathrm{ml}, 50 \mu \mathrm{g} / \mathrm{ml}$ and $100 \mu \mathrm{g} / \mathrm{ml}$. The solution was incubated at room temperature for $30 \mathrm{~min}$ and analyzed spectrometrically at $517 \mathrm{~nm}$. DPPH radical scavenging activity was calculated as percent inhibition. IC50 determined 50\% inhibition of DPPH radical formation and capacity of DPPH radical scavenging activity was determined compared with vitamin $\mathrm{C}$ as standard antioxidant.

$$
\text { Radical scavenging activity }=\frac{\text { Ablank }- \text { Asample }}{\text { Ablank }} \times 100
$$

where Ablank and Asample were absorbance data of control and sample, respectively.

\section{Ferric reducing antioxidant power (FRAP)}

Reducing scavenging activity was observed using FRAP method according to Amarowicz. ${ }^{24}$ Briefly, extracts were mixed with frap reagent containing $300 \mathrm{mM}$ acetate buffer, $10 \mathrm{mM}$ TPTZ and $20 \mathrm{mM}$ ferric chloride, and incubated at $37^{\circ} \mathrm{C}$ for $30 \mathrm{~min}$ in the dark condition. Ferrous tripyridyltriazine product were measured using spectrophotometer at $593 \mathrm{~nm}$. FRAP value was expressed as mmol ferrous sulfate equivalent/g of sample dried weight.

\section{Isolation of LDL}

Process of human LDL isolation was approved by Mahasarakham University Ethics committee. LDL was isolated using floating sequential ultra- centrifugation method, described previously. ${ }^{25}$ Briefly, LDL was isolated from fresh plasma of fasting overnight, healthy volunteers. Fresh plasma containing $4 \mathrm{mM}$ EDTA and $1 \mathrm{mM}$ phenylmethanesulfonyl fluoride (PMSF) as serine protease inhibitor. Adjusted density of plasma is $1.21 \mathrm{~g} / \mathrm{ml}$ with solid potassium bromide $(\mathrm{KBr})$. High density plasma was loaded to the lower part of ultracentrifuge tube, which was overlaid by gradient salt solutions, $1.063,1.019$ and $1.005 \mathrm{~g} / \mathrm{ml}$, respectively. LDL was isolated by ultracentrifugation at $286,000 \mathrm{~g}$ at $4^{\circ} \mathrm{C}$ for $24 \mathrm{~h}$. The yellowish LDL fraction was collected between $1.019-1.063 \mathrm{~g} / \mathrm{ml}$ densities and dialyzed using phosphate buffer saline ( $\mathrm{pH} 7.38-7.42)$ with nitrogen flow at $4^{\circ} \mathrm{C}$ for $24 \mathrm{~h}$. LDL was filtered through $0.22 \mu \mathrm{m}$ pore size membrane and then measured using bicinchoninic acid (BCA) assay. ${ }^{26}$

\section{Assessment of lipid peroxidation Thiobarbituric reactive substance (TBARs)}

Malondialdehyde (MDA) is indicated as a product of lipid. MDA level was determined based on the reaction with thiobarbituric acid (TBA). ${ }^{27}$ The reaction was divided into two parts; the preliminary part was divided into three groups, no treated, $\mathrm{LDL}-\mathrm{Cu}_{2} \mathrm{SO}_{4}$ co-incubation and pretreated of $L$. leucocephala and LDL prior to the incubation with $\mathrm{Cu}_{2} \mathrm{SO}_{4}$. The experiment part was the observation of anti-lipidperoxidation activity in HUVC. The assessment of lipid peroxidation activity was determined by incubation of the mixture with trichloroacetic acid (TCA) and thiobarbituric acid (TBA) in an acidic $\mathrm{pH}$ condition at $90^{\circ} \mathrm{C}$ for $20 \mathrm{~min}$. The reaction was precipitated by centrifucation at $4,000 \mathrm{~g}$ for $10 \mathrm{~min}$ at $4^{\circ} \mathrm{C}$. MDA level was read using UV spectrophotometer at $532 \mathrm{~nm}$. TBARs value was calculated using 1, 1, 3, 3-tetraethoxypropane as MDA standard curve.

\section{Conjugated diene formation}

Conjugated diene developed in LDL through oxidation of poly-unsaturated fatty acids (PUFAs) was observed. One milligram protein of LDL was incubated with $0.01 \mathrm{mg} / \mathrm{ml} \mathrm{L}$. leucocephala solution for $1 \mathrm{~h}$ at room temperature. oxLDL was induced using $10 \mu \mathrm{M} \mathrm{Cu}_{2} \mathrm{SO}_{4}$. Kinetic of LDL oxidation was monitored the changes of conjugated diene at the absorbance of $234 \mathrm{nM}$ as described previously. ${ }^{28}$ The absorbance curve was comprised of three phases; lag phase, propagation phase and decomposition phase. Initial stage of LDL oxidation is lag phase time in which oxidant primary interacted with LDL. Prolong of lag phase time was referred to antioxidant activity of LDL. Lastly, decomposition phase is where LDL is completely oxidized, and OD value is stable.

\section{HUVCs cultured}

Endothelial cells function, and antioxidant capacity of vascular cells were determined in HUVC system. The process was approved by Mahasarakham University Ethics Committee. Umbilical veins were dissected from human umbilical cord of normal labor. Umbilical cord was processed within $2 \mathrm{~h}$ after vaginal delivery. With some modifications, umbilical veins were cultured according to Friedman $\mathrm{R}$ et al. ${ }^{29}$ Briefly, umbilical veins were dissected into ring with range 3-4 millimeters under strictly sterile technique and the rings are placed in 24 well plate cultured containing $2 \mathrm{ml}$ of RPMI 1640 culture media (GIBCO $)$ supplemented with $10 \%$ FCS with $100 \mu \mathrm{g} / \mathrm{ml}$ gentamycin and $10 \mu \mathrm{g} / \mathrm{ml}$ ampicillin. Cultures were maintained at $37^{\circ} \mathrm{C}$ in $5 \% \mathrm{CO}_{2}$ incubator with $95 \% \mathrm{O}_{2}$ flow for four days. Oxidative stress was induced in HUVCs using different concentration of glucoses $(7,14,50 \mathrm{mM})$ and/or $40 \mu \mathrm{g} / \mathrm{ml}$ oxLDL in each group. Concentration $0.1,0.5$ and $1 \mathrm{mg} / \mathrm{mL}$ of $L$. leucocephala were subsequently incubated in the culture for two days. HUVCs were rinsed with phosphate buffer saline (PBS) $\mathrm{pH}$ 7.37-7.47 before determination of SOD activity and NO level of vascular cells. 


\section{Real-time measurement of NO production}

Real time production of $\mathrm{NO}$ in vascular endothelial cells was monitored using model inNO-T, NO measuring system with an amiNO-700 probe (Innovative Instruments, Inc., Tampa, FL), based on direct oxidation of NO to nitrite. ${ }^{30,31}$ Briefly, microelectrode probe was calibrated with calibration solution $\left(1 \mathrm{M} \mathrm{H}_{2} \mathrm{SO}_{4}, 20 \mathrm{mg} \mathrm{KI}\right.$ and $18 \mathrm{ml}$ of $\left.\mathrm{ddH}_{2} \mathrm{O}\right)$ prior to use. Picoamparer ( $\mathrm{pA}$ ) was adjusted to zero and calibrated by adding nitrite at different concentrations as following; $25 \mathrm{nM}, 50 \mathrm{nM}, 100 \mathrm{nM}, 150 \mathrm{nM}$, and $200 \mathrm{nM}$. NO concentration was reported in $\mathrm{nM}$.

\section{SOD activity}

SOD, an important scavenging enzyme for superoxide anion $\left(\mathrm{O}_{2}{ }^{\circ}\right)$, was determined for its activity using xanthine oxidase method. HUVCs were homogenized and ultracentrifuged at 12,000 g for $15 \mathrm{~min}$. Aqueous of homogenate was aspirated and determined SOD activity using SOD determination kit (Fluka). The solutions and standard tube were mixed and incubated at $37^{\circ} \mathrm{C}$ for $20 \mathrm{~min}$. SOD activity was determined spectrophotometrically at $450 \mathrm{~nm}$. Calculated of SOD activity was showed in percent inhibition of $\mathrm{O}_{2}^{-}$production as the equation and reported in $\mathrm{U} / \mathrm{ml} / \mathrm{mg}$ tissue.

\section{Morphology in HUVCs}

HUVCs were sectioned according to embedding paraffin method. ${ }^{32}$ Briefly, the tissue was fixed, dehydrated and embedded in paraffin. The paraffin embedded tissue was then sectioned and deparafinized on a slide, followed by staining process using hematoxylin and eosin. The morphological changes were observed under light microscope.

\section{Statistical analysis}

All variables were summarized using means and standard deviations (SD). Statistical analysis was carried out to compare between groups by Kruskal-Wallis tests, and followed by Dunn's method for multiple comparison. Statistical significant was consider when $p$-value is less than 0.05. (R 3.4.0).

\section{RESULTS}

\section{Antioxidant contents}

TPC and TFC contents was measured using the Folin-Ciocalteu method and aluminum chloride colorimetric method, respectively. The results showed that total phenolic of leaves dry weight of $L$. leucocephala at $1 \mathrm{~g}$ was found $51.04 \pm 0.91 \mathrm{mg} \mathrm{GAE} / \mathrm{g}$. Whereas, TFC was showed 0.13 $\pm 0.01 \mathrm{mg}$ catechin $/ \mathrm{g}$.

\section{Antioxidant and anti-lipid peroxidation activity of L. leucocephala}

Antioxidant activities were determined by using DPPH and FRAP methods. IC50 concentration of leave extract measured by DPPH method was $369.6 \mu \mathrm{g} / \mathrm{ml}$, that is $576.79 \mu 16.08 \mu \mathrm{g}$ of vitamin $\mathrm{C}$ equivalent $/ \mathrm{mg}$ of leave extract. The reducing power activity using FRAP method exhibited dried extract at $428.54 \pm 15.32 \mathrm{mM}$ FeII equivalent/g.
Anti-lipid peroxidation activity of L. leucocephala was observed in $\mathrm{Cu}_{2} \mathrm{SO}_{4}$-induced diene formation in isolated LDL. The result showed lag phase time was slightly longer in $0.1 \mathrm{mg} / \mathrm{ml}$ of $L$. leucocephala treated condition, in contrast with $44 \pm 3.3 \%$ approximately lower of MDA concentration Table 1 .

\section{Effect of L. leucocephala on vascular cell of Human Umbilical Vein Cultured NO concentration}

Influence of L. leucocephala in NO production was conducted under model in NO-T with amino-700 probe. The experiments were observed in HUVC-induced pre-obese condition using $40 \mu \mathrm{g} / \mathrm{ml}$ oxLDL and $7 \mathrm{nM}$ glucose. Compared with positive control (without L. leucocephala), the result showed that NO concentration was significantly reduced when leave extracts at concentration of $0.05,0.5$ and $1 \mathrm{mg} / \mathrm{mL}$ were added Figure 1 . However, only the leave extract at concentration of $0.1 \mathrm{mg} / \mathrm{mL}$ significantly increase NO level $(p<0.05)$.

\section{Superoxide dismutase (SOD) activity}

Scavenging of $\mathrm{O}_{2}{ }^{-}$by SOD enzyme was performed using SOD determination kits-WST (Dojindo) and displayed in percent inhibition of $\mathrm{O}_{2}{ }^{--}$production Figure 2. The experiments were demonstrated using pre-obese condition. Adding $0.1 \mathrm{mg} / \mathrm{ml}$ of L. leucocephala, SOD activity was significantly increased compared with control and positive control $(p<0.005$ and $p<0.05$, respectively). In contrast, 0.5 and $1 \mu \mathrm{g} / \mathrm{ml}$ of leave extracts significantly reduced SOD activity compared with both control $(p<0.001$ and $p<0.005$, respectively) and positive control $(p<0.005)$.

\section{Assessment of lipid peroxidation}

Figure 3 have shown MDA concentration $(\mathrm{mmol} / \mathrm{mg})$, an indicator for lipid peroxidation. The experiment was performed using TBAR assay to indicate level of MDA in the pre-obese induced system. The result showed that only $L$. leucocephala at concentration $0.05 \mathrm{mg} / \mathrm{ml}$ can maintain level of lipid peroxidation compared with control group. When leave extract concentration was increased, the result also exhibited the dose response relationship of the extract and MDA concentration Figure 3.

\section{Morphology of HUVCs}

Morphology of HUVCs were observed under 20x light microscope Figure 4. The result showed migration of smooth muscle cells in LDL and glucose induced oxidative stress comparing with control group Figure 4A and 4B. Moreover, intact of vascular cell was clearly reduced, in parallel with death of vascular smooth muscle cells and endothelial cells. In contrast, $0.05 \mathrm{mg} / \mathrm{ml}$ of $L$. leucocephala treated with LDL and glucose induced oxidative stress showed similarity of HUVCs morphology compared with control Figure $4 \mathrm{~A}$ and $4 \mathrm{C}$. When concentration of extract was increased, at dose $0.1 \mathrm{mg} / \mathrm{ml}$ leave extract resulted in increase of smooth muscle cells density and migration Figure 4D. Interestingly, at dose 0.5 and $1 \mathrm{mg} / \mathrm{ml}$ leave extracts, the results showed obviously reduction in vascular cells and change in nucleus morphology Figure $4 \mathrm{E}$ and $4 \mathrm{~F}$.

Table 1: Effect of $L$. leucocephala in LDL oxidation. Lag phase is determined in the initial step of diene formation curve.

\begin{tabular}{ccc}
\hline & Lag phase time (minutes) & MDA (nmol/mg LDL protein) \\
\hline $\mathrm{LDL}$ & $>90-120$ & $10.5 \pm 0.62$ \\
$\mathrm{LDL}+10 \mu \mathrm{m} \mathrm{Cu}_{2} \mathrm{SO}_{4}$ & $38-70$ & $29.35 \pm 2.62$ \\
$\mathrm{LDL}+10 \mu \mathrm{m} \mathrm{Cu}_{2} \mathrm{SO}_{4}+0.1 \mathrm{mg} / \mathrm{ml} L L$ & $65-85$ & $23.45 \pm 1.69$ \\
\hline
\end{tabular}

Note: LDL oxidation was determined of final concentration at $0.1 \mathrm{mg} / \mathrm{ml}$ of $L$. leucocephala $(L L)(\mathrm{n}=5)$. Data were express as Mean \pm SD. 


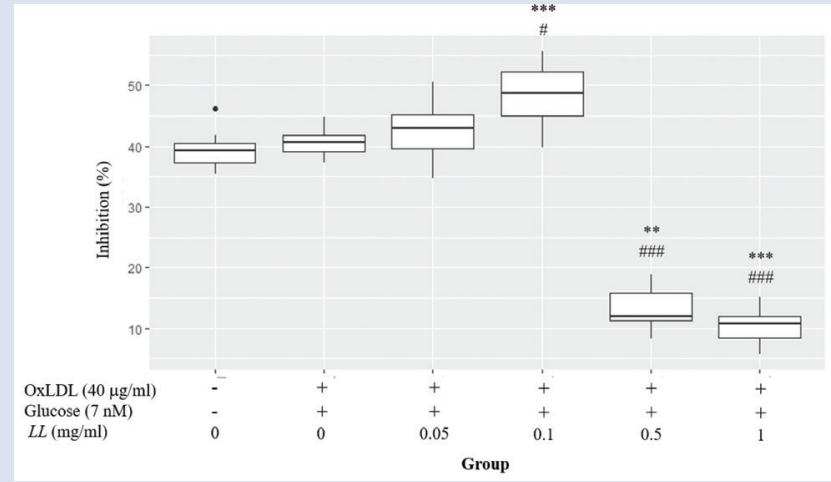

Figure 1: NO concentration under pre-obese induced condition. *Significantly different from control group $\left({ }^{*} p<0.05\right),\left({ }^{* *} p<0.01\right)$, $(* * * 0<0.005)$. \#Significantly different from positive control group (\# $p<0.05)$, (\#\# $p<0.01$ ), (\#\#\# $<<0.005)$. OxLDL indicated for oxidized LDL. LL indicated for Leucaena leucocephala.

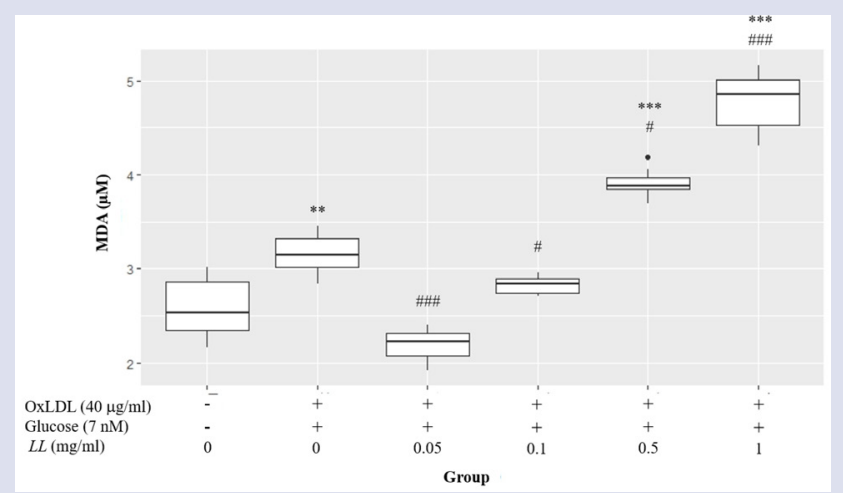

Figure 3: Concentration of MDA, an indicator of lipid peroxidation, in pre-obese induced condition. * Significantly different from control group ( $\left.\left.\left.{ }^{*} p<0.05\right),{ }^{* *} p<0.01\right),{ }^{* * *} p<0.005\right)$. \#Significantly different

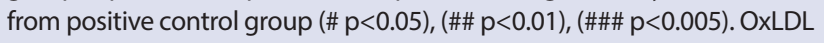
indicated for oxidized LDL. LL indicated for Leucaena leucocephala.

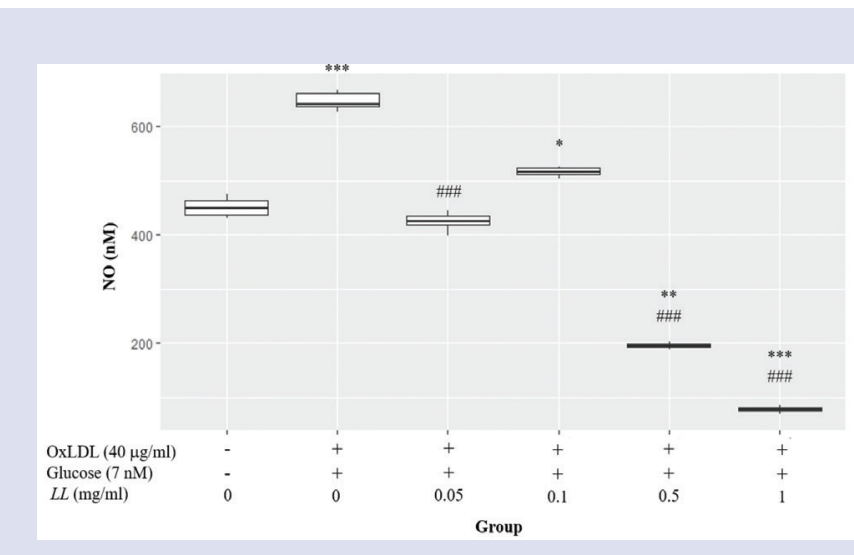

Figure 2: Level of SOD activity reported as percent inhibition of superoxide anion production in pre-obese induced condition. ${ }^{*}$ Significantly different from control group $\left({ }^{*} p<0.05\right)$, ( $\left.{ }^{* *} p<0.01\right)$, $(* * * p<0.005)$. \#Significantly different from positive control group (\# $p<0.05$ ), (\#\# $p<0.01$ ), (\#\#\# $p<0.005)$. OxLDL indicated for oxidized LDL. LL indicated for Leucaena leucocephala.

\section{Conclusion and discussion}

Impaired fasting blood glucose is caused by increasing of glucose concentration in fasting state, but the patients with IFG have not already develop diabetes mellitus. Those with IFG might eventually develop CVS by glucose inducing oxidative stress production. ${ }^{1}$ Thus, to promote reduction of oxidative stress, this study aims to observe antioxidant activity of L. leucocephala in endothelium function using impair fasting glucose in human umbilical vein cultured (HUVCs) model.

Total phenolic and flavonoid contents was determined, and the result showed $51.04 \pm 0.91 \mathrm{mgGAE} / \mathrm{g}$ and $0.13 \pm 0.01 \mathrm{mg}$ of catechin/g content in dry leave extract, respectively. Likewise, other studies that found phenolic at $3.21 \mathrm{mg} \mathrm{GAE} / \mathrm{g},{ }^{33} 37.38 \pm 0.49 \mathrm{mg} \mathrm{GAE} / \mathrm{g},{ }^{17} 78.8 \mathrm{~g}$ GAE/100g extract, ${ }^{18} 258.4 \pm 7.45 \mathrm{mg} \mathrm{GAE} / \mathrm{g},{ }^{16} 7.51$ to $12.06 \mathrm{mg} \mathrm{GAE} / \mathrm{g},{ }^{34}$ and flavonoid contents at $159.61 \pm 12.79 \mathrm{mg}$ QE/g (Quercetin equivalent), ${ }^{16} 2.80$ to $3.59 \mathrm{mg} \mathrm{QE} / \mathrm{g}^{34}$ depended on parts of plant collection and solution extracted. This compon ents suggest antioxidant activities of
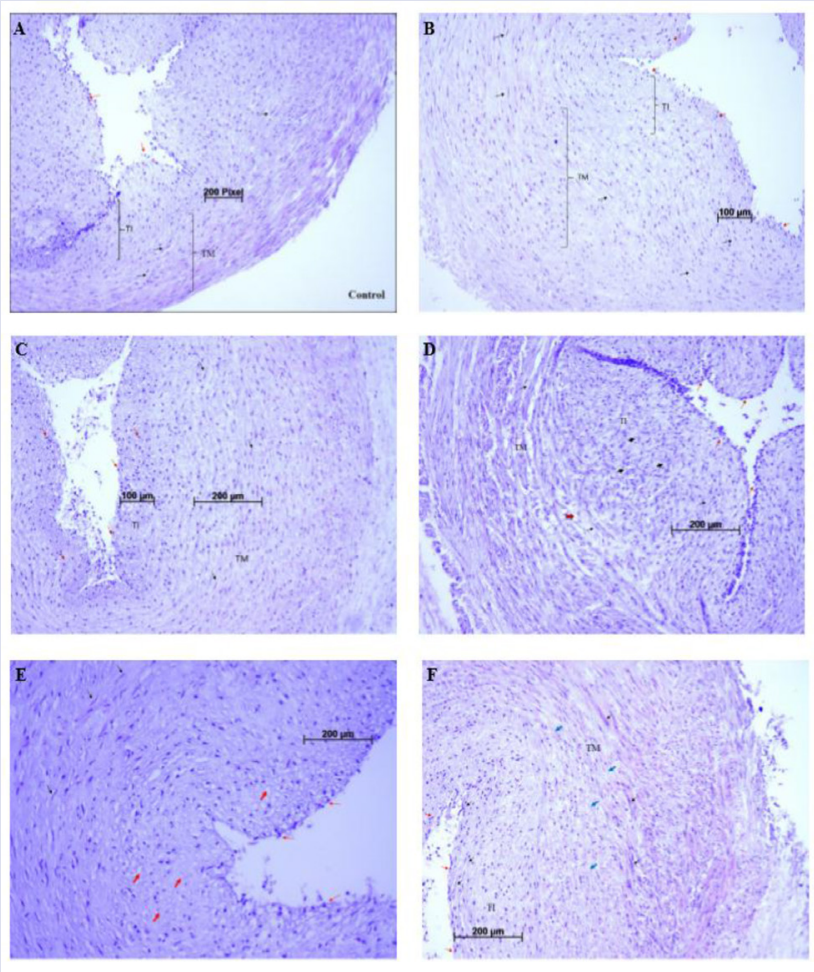

Figure 4: Morphological changes in HUVC. A, control group. B, LDL and glucose induced oxidative stress in HUVC. $C, 0.05 \mathrm{mg} / \mathrm{ml}$ of $L$. leucocephala treated with LDL and glucose induced oxidative stress in HUVCs. D, $0.1 \mathrm{mg} / \mathrm{ml}$ of L. leucocephala treated with LDL and glucose induced oxidative stress in HUVCs. E, $0.5 \mathrm{mg} / \mathrm{ml}$ of L. leucocephala treated with LDL and glucose induced oxidative stress in HUVCs. $\mathrm{F}, 1 \mathrm{mg} / \mathrm{ml}$ of $L$. leucocephala treated with LDL and glucose induced oxidative stress in HUVCs. 
L. leucocephala, as confirmed in Table 1 . The preliminary study indicated that $L$. leucocephala provides antioxidant activity using DPPH method resulting in $50 \%$ scavenging activity at $369.6 \mu \mathrm{g} / \mathrm{ml}$, which is equivalent to $576.79 \pm 16.08 \mu \mathrm{g}$ of vitamin C equivalent $/ \mathrm{mg}$. The result was confirmed by FRAP method showing the reducing power activity of dried extract at $428.54 \pm 15.32 \mathrm{mM}$ FeII equivalent/g. This result showed higher scavenging activity comparing to previous study ${ }^{16}$ that observing the activity in seed extract ${ }^{17,18}$, suggested leave extract might provide greater scavenging activity compared with the seed part.

The effects of L. leucocephala on HUVCs metabolites were shown in Figure 1 to 4, despite on each category. Figure 1 showed NO production in L. leucocephala preincubated HUVCs. The result shown that L. leucocephala significantly influenced NO production in HUVCinduced pre-obese condition at the concentration of $0.1 \mathrm{mg} / \mathrm{mL}$, but maintained its level at $0.05 \mathrm{mg} / \mathrm{mL}$. On the other hand, result in Figure 2 showed that induction of SOD activity was gradually increased in parallel with concentrations of leave extract $(0.05$ and $0.1 \mathrm{mg} / \mathrm{mL})$, before significantly decreasing at dose 0.5 and $1 \mathrm{mg} / \mathrm{mL}$. The alteration of HUVCs activity in high dose of leave extracts might suggest the death of those vascular cells as observed in Figure 4. In assessment of lipid peroxidation activity in HUVCs, MDA concentration, an indicator of lipid peroxidation, was determined in Figure 3. The result showed decreasing of MDA level in $0.05 \mathrm{mg} / \mathrm{mL}$ L. leucocephala treated group, and gradually in dose response concentration in L. leucocephala concentration of $0.1,0.5$ and $1 \mathrm{mg} / \mathrm{mL}$, respectively. These results were verified in culture of HUVCs Figure 4. With histology of vascular cells, the result showed that the vascular cells were obviously dead in HUVC-induced pre-obese condition. In this condition of increasing extracellular glucose, it was suggested to induce endothelial cell dysfunction by increased activation of NADPH oxidase and IL $1 \beta,{ }^{35,36,37}$ which might eventually lead to senescence of the cells. When $0.05 \mathrm{mg} / \mathrm{mL}$ of leave extracts were pre-incubated in the system, the overall of vascular cells have been found resembling the control group. It suggested the healthy condition of HUVCs as L. leucocephala has been found to provide the activity to reduce blood glucose level in diabetic rats ${ }^{17}$ by increasing of glucose uptake into cells. ${ }^{38}$ In comparison with $L$. leucocephala at concentration of $0.1 \mathrm{mg} / \mathrm{mL}$, smooth muscle cells migration was observed in Figure 4C, suggested this dose may performed the activity of pro-oxidant agent by activating NAPPH oxidase, induces inducible nitric oxide synthase (iNOS) activity of vascular smooth muscle cell. ${ }^{39}$ In addition, ROS may also act as vascular endothelial growth factor (VEGF) which induces vascular cells migration and proliferation. ${ }^{40}$ With the production of $\mathrm{NO}$, it can interact with superoxide anions $\left(\mathrm{O}_{2}^{-}\right)$and results in peroxynitrite production, which is a radical that can induce endothelial dysfunction and damage cells..$^{19,41}$ Although no cell death have been observed. This condition may explain the increasing in NO level and SOD activity Figure 1 and Figure 2, respectively as for the oxidation process have been introduced. The MDA level in Figure 3 also confirmed this probability as the lipid peroxidation was slightly increased.

At the higher concentration of L. leucocephala, the result of both NO level and SOD activity were significantly decreased Figure 1 and 2, respectively. These events may suggest endothelial cell dysfunction and damage, because of mimosine, a toxic component of $L$. leucocephala. ${ }^{42,43,44}$ With this result, it is suggested that this toxic activity may be applied to the inhibitory effect on proliferation of cancer. ${ }^{45}$

In conclusion, this study has been performed to exhibit the antioxidant activity of L. leucocephala in endothelium functions and has been found to have an appropriate concentration at 0.05 and $0.1 \mathrm{mg} / \mathrm{mL}$ in reducing oxidative stress condition in impaired fasting blood glucose patients. The higher doses of leave extracts may introduce the toxic effect to endothelial cells, which may contribute to a plausible way to inhibit angiogenesis of cancer cell. Nevertheless, the optimal level for toxic activity in inhibition of cancer angeiogenesis should be further investigated. As well as the underlying mechanism of how L. leucocephala affects in oxidative stress in condition of having impaired fasting glucose has been performed should be further validated.

\section{ACKNOWLEDGEMENT}

This study was funded by Faculty of Medicine, Mahasarakham University.

\section{CONFLICTS OF INTEREST}

The authors declare that there is no conflict of interest regarding the publication of this article.

\section{ABBREVIATION USED}

LL: Leucaena leucocephala; LDL: low-density lipoprotein; oxLDL: oxidized low-density lipoprotein; HUVCs: human umbilical vein cultured; SOD: superoxide anion; NO: nitric oxide; GAE: gallic equivalent; DW: dried weight; DPPH: 1,1-diphenyl-2 picryhydrazyl; MDA: malondialdehyde; IFG: impaired fasting glucose; ROS: reactive oxygen species; CVS: cardiovascular diseases; NCDs: noncommunicable diseases; TPC: total phenolic content; TFC: total flavonoid content; FRAP: ferric reducing antioxidant power; TBAR: thiobarbituric acid reactive substance; BCA: bicinchoninic acid; TCA: trichloroacetic acid; TBA: thiobarbituric acid; PUEAs: polyunsaturated fatty acid; PBS: phosphate buffer saline.

\section{REFERENCES}

1. Shaw JE, Zimmet PZ, Courten M, Dowse GK, Chitson P, Gareeboo H, et al. Impaired fasting glucose or impaired glucose tolerance. What best predicts future diabetes in Mauritius? Diabetes Care.1999;22(3):399-402

2. Ceriello A, Motz E. Is Oxidative Stress the Pathogenic Mechanism Underlying Insulin Resistance, Diabetes, and Cardiovascular Disease? The Common Soil Hypothesis Revisited. Arteriosclerosis Thrombosis Vascular Biol. 2004;24(5): 816-23.

3. Wright E, Scism-Bacon JL, Glass LC. Oxidative stress in type 2 diabetes: the role of fasting and postprandial glycaemia. Inter J Clinical Practice. 2006; 60(3):308-14

4. Ghebre YT, Yakubov E, Wong WT, Krishnamurthy P, Sayed N, Sikora AG, et al. Vascular Aging: Implications for Cardiovascular Disease and Therapy. Translational Med Sunnyvale Calif [Internet]. 2016:6(4) [cited 2017 Oct 9]. Available from: https://www.ncbi.nlm.nih.gov/pmc/articles/PMC5602592/.

5. Simó R, Ballarini S, Cunha-Vaz J, Ji L, Haller H, Zimmet $P$, et al. Non-Traditional Systemic Treatments for Diabetic Retinopathy: An Evidence-Based Review. Current Med Chem. 2015;22(21):2580-9.

6. Reho JJ, Rahmouni K. Oxidative and inflammatory signals in obesity-associated vascular abnormalities. Clinical Sci. 2017;131(14):1689-700.

7. Virdis A. Endothelial Dysfunction in Obesity: Role of Inflammation. High Blood Press Cardiovasc Prevention Off J Ital Society Hypertension. 2016;23(8):83-5.

8. Infante T, Forte $\mathrm{E}$, Aiello M, Salvatore $\mathrm{M}$, Cavaliere $\mathrm{C}$. in vivo and in vitro Analysis in Coronary Artery Disease Related to Type 2 Diabetes. Front Endocrinol [Internet]. 2017;8. Available from: https://www.ncbi.nlm.nih.gov/pmc/articles/ PMC5566996/.

9. Bourgoin F, Bachelard H, Badeau M, Mélançon S, Pitre M, Larivière R, et al. Endothelial and vascular dysfunctions and insulin resistance in rats fed a high-fat, high-sucrose diet. Am J Physiology Heart Circulatory Physiol. 2008;295(3):H1044-55.

10. Bruno RM, Penno G, Daniele G, Pucci L, Lucchesi D, Stea F, et al. Type 2 diabetes mellitus worsens arterial stiffness in hypertensive patients through endothelial dysfunction. Diabetologia. 2012;55(6):1847-55

11. Shen K-P, Lin H-L, Chang W-T, Lin J-C, An L-M, Chen I-J, et al. Eugenosedin-A ameliorates hyperlipidemia-induced vascular endothelial dysfunction via inhibition of $\alpha 1$-adrenoceptor/5-HT activity and NADPH oxidase expression. Kaohsiung Med Sci. 2014;30(3):116-24

12. Gradinaru D, Borsa C, lonescu C, Prada GI. Oxidized LDL and NO synthesis-Biomarkers of endothelial dysfunction and ageing. Mech Ageing Dev. 2015; 151:101-13.

13. Meisinger $\mathrm{C}$, Baumert J, Khuseyinova N, Loewel H, Koenig W. Plasma oxidized low-density lipoprotein, a strong predictor for acute coronary heart disease events in apparently healthy, middle-aged men from the general population. Circulation 2005;112(5):651-7.

14. Walter MF, Jacob RF, Jeffers B, Ghadanfar MM, Preston GM, Buch J, et al. 
Serum levels of thiobarbituric acid reactive substances predict cardiovascular events in patients with stable coronary artery disease: a longitudinal analysis of the PREVENT study. J Am Coll Cardiology. 2004;44(10):1996-2002.

15. Hassan RA, Tawfik WA, Abou-Setta LM. The flavonoid constituents of Leucaena leucocephala. Growing in Egypt, and their biological activity. African J Traditional, Complement Alternative Med AJTCAM. 2014;11(1):67-72.

16. Dzoyem JP, Eloff JN. Anti-inflammatory, anticholinesterase and antioxidant activity of leaf extracts of twelve plants used traditionally to alleviate pain and inflammation in South Africa. J Ethnopharmacology. 2015;160:194-201.

17. Chowtivannakul P, Srichaikul B, Talubmook C. Antidiabetic and antioxidant activities of seed extract from Leucaena leucocephala (Lam.) de Wit. Agric Nat Resources. 2016;50(5):357-61.

18. Benjakul S, Kittiphattanabawon P, Sumpavapol P, Maqsood S. Antioxidant activities of lead (Leucaena leucocephala) seed as affected by extraction solvent, prior dechlorophyllisation and drying methods. J Food Sci Technol. 2014;51(11):3026-37.

19. Pitocco D, Zaccardi F, Di Stasio E, Romitelli F, Santini SA, Zuppi C, et al. Oxidative stress, nitric oxide, and diabetes. Rev Diabetic Stud RDS. 2010;7(1):15-25.

20. Cai H, Harrison DG. Endothelial dysfunction in cardiovascular diseases: the role of oxidant stress Circulation Res. 2000;87(10):840-4

21. khatoon $M$, Islam E, Islam R, Rahman AA, Alam AK, Khondkar P, et al. Estimation of total phenol and in vitro antioxidant activity of Albizia procera leaves. Bio Med Central Res Notes. 2013;6(1):121.

22. Zhishen J, Mengcheng T, Jianming W. The determination of flavonoid contents in mulberry and their scavenging effects on superoxide radicals. Food Chem. 1999;64(4):555-9.

23. Deng J, Cheng W, Yang G. A novel antioxidant activity index (AAU) for natural products using the DPPH assay. Food Chem. 2011;125(4):1430-5.

24. Amarowicz R, Naczk M, Shahidi F. Antioxidant activity of various fractions of non-tannin phenolics of canola hulls. J Agric Food Chem. 2000;48(7):2755-9.

25. Schumaker VN, Puppione DL. [6] Sequential flotation ultracentrifugation. Methods Enzymology. 1986;128:155-70.

26. Smith PK, Krohn RI, Hermanson GT, Mallia AK, Gartner FH, Provenzano MD et al. Measurement of protein using bicinchoninic acid. Anal Biochemistry. 1985;150(1):76-85

27. Olszewska-Stonina DM, Matewski D, Czajkowski R, Olszewski KJ, WoŸniak A, Odrowaz-Sypniewska $\mathrm{G}$, et al. The concentration of thiobarbituric acid reactive substances (TBARS) and paraoxonase activity in blood of patients with osteoarthrosis after endoprosthesis implantation. Med Sci Monitor Inter Med J Experimental Clinical Res. 2011;17(9):CR498-CR504.

28. Esterbauer H, Gebicki J, Puhl H, Jürgens G. The role of lipid peroxidation and antioxidants in oxidative modification of LDL. Free Radical Biology Med. 1992:13(4):341-90

29. Friedman R, Betancur M, Boissel L, Tuncer H, Cetrulo C, Klingemann H. Umbilical Cord Mesenchymal Stem Cells: Adjuvants for Human Cell Transplantation. Biology Blood Marrow Transplant. 2007;13(12):1477-86

30. Shibuki K. An electrochemical microprobe for detecting nitric oxide release in brain tissue. Neuroscience Res. 1990;9(1):69-76.

31. Christodoulou D, Kudo S, Cook JA, Krishna MC, Miles A, Grisham MB, et al.
Electrochemical methods for detection of nitric oxide. Methods Enzymology. 1996;268:69-83

32. Hewitt SM, Lewis FA, Cao Y, Conrad RC, Cronin M, Danenberg KD, et al. Tissue Handling and Specimen Preparation in Surgical Pathology: Issues Concerning the Recovery of Nucleic Acids from Formalin-Fixed, Paraffin-Embedded Tissue. Arch Pathology Lab Med. 2008;132(12):1929-35.

33. Zarin MA, Wan HY, Isha A, Armania N. Antioxidant, antimicrobial and cytotoxic potential of condensed tannins from Leucaena leucocephala hybrid-Rendang. Food Sci Hum Wellness. 2016;5(2):65-75.

34. Sharma P, Chaurasia S. Evaluation of Total Phenolic, Flavonoid Contents and Antioxidant Activity of Acokanthera oppositifolia and Leucaena leucocephala. International Journal of Pharmacognosy and Phytochemical Research. 2015; 7:175-80.

35. Peiró C, Romacho T, Azcutia V, Villalobos L, Fernández E, Bolaños JP, et al. Inflammation, glucose, and vascular cell damage: the role of the pentose phosphate pathway. Cardiovasc Diabetology. 2016;15(1):82.

36. Lafuente N, Matesanz N, Azcutia V, Romacho T, Nevado J, Rodríguez-Mañas L, et al. The deleterious effect of high concentrations of D-glucose requires pro-inflammatory preconditioning. J Hypertension. 2008;26(3):478-85.

37. Vallejo S, Palacios E, Romacho T, Villalobos L, Peiró C, Sánchez-Ferrer CF. The interleukin-1 receptor antagonist anakinra improves endothelial dysfunction in streptozotocin-induced diabetic rats. Cardiovasc Diabetology. 2014:13(1):158.

38. Kuppusamy UR, Arumugam B, Azaman N, Jen Wai C. Leucaena leucocephala Fruit Aqueous Extract Stimulates Adipogenesis, Lipolysis, and Glucose Uptake in Primary Rat Adipocytes. Sci World J [Internet]. 2014 [cited 2017 Oct 2]:2014. Available from: https://www.ncbi.nlm.nih.gov/pmc/articles/PMC4142670/.

39. MacNaul KL, Hutchinson NI. Differential expression of iNOS and cNOS mRNA in human vascular smooth muscle cells and endothelial cells under norma and inflammatory conditions. Biochemical Biophysical Res Communications. 1993;196(3):1330-4

40. Kuroki M, Voest EE, Amano S, Beerepoot LV, Takashima S, Tolentino M, et al. Reactive oxygen intermediates increase vascular endothelial growth factor expression in vitro and in vivo. J Clinical Invest. 1996;98(7):1667-75.

41. Moreira JD, Pernomian L, Gomes MS, Moreira RP, Prado AF, Silva CHTP, et al. Enhanced nitric oxide generation from nitric oxide synthases as the cause of increased peroxynitrite formation during acute restraint stress: Effects on carotid responsiveness to angiotensinergic stimuli in type-1 diabetic rats. Euro J Pharmacology. 2016;783:11-22.

42. Chou CH, Kuo YL. Allelopathic research of subtropical vegetation in Taiwan: III. Allelopathic exclusion of understory by Leucaena leucocephala (Lam.) de Wit. J Chemical Ecol. 1986;12(6):1431-48.

43. Murakoshi I, Ikegami F, Hinuma Y, Hanma Y. Purification and characterization of L-mimosine synthase from Leucaena leucocephala. Phytochemistry. 1984 23(9):1905-8.

44. Ilham Z, Hamidon H, Rosji NA, Ramli N, Osman N. Extraction and Quantification of Toxic Compound Mimosine from Leucaena leucocephala Leaves. Procedia Chem. 2015;16:164-70.

45. Dong Z, Zhang J-T. EIF3 p170, a Mediator of Mimosine Effect on Protein Synthesis and Cell Cycle Progression. Molecular Biology of the Cell. 2003;14(9):3942-51.

\section{GRAPHICAL ABSTRACT}

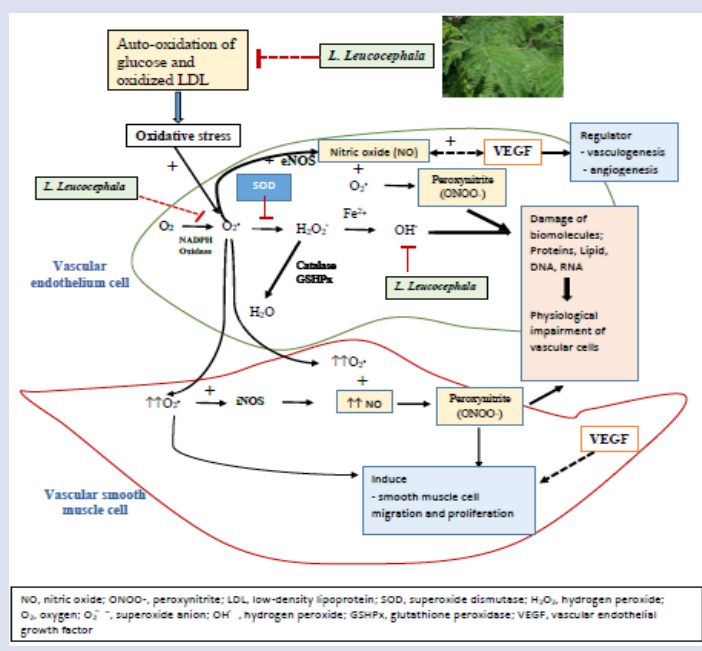

\section{ABOUT AUTHORS}

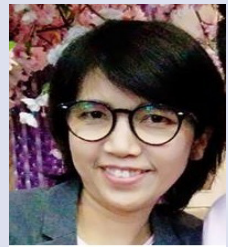

Ratikorn Chatchanayuenyong: Biomedical Department, Faculty of Medicine, Mahasarakham University, Mahasarakham, THAlLAND.

Cite this article: Chatchanayuenyong R, Sujayanont P, Vuttivirojana A. Effects of Leucaena leucocephala (Lam.) de Wit Leaves Extracts in Culture of Human Umbilical Vein Cells. Pharmacog J. 2018;10(1):148-53. 